Journal of Case Reports 2017;7(1):30-32

\title{
Placental Chorioangioma: Usual Presentation and Alternate Treatment Options
}

\author{
Gowri Vaidyanathan, Aneeta Bai, Jaykumari Perchani, Hana El Said, Ritu Lakhtakia \\ Department of Obstetrics \& Gynecology, Sultan Qaboos University, Muscat, Oman.
}

\section{Corresponding Author: \\ Dr. Gowri Vaidyanathan \\ Email: gowrie61@hotmail.com}

This is an Open Access article distributed under the terms of the Creative Commons Attribution License (creativecommons.org/ licenses/by/3.0).

Received Accepted Published

September 24, 2016

December 24, 2016

January 20, 2017

\begin{abstract}
Background: Placental chorioangiomas are common benign tumors with an incidence of $0.6 \%$. Case Report: A 23 year old primigravida was diagnosed to have a placental mass of about $4 \mathrm{cms}$ chorioangioma during routine ultrasound at 22 weeks gestation. She was on regular follow up, at 31 weeks gestation the mass increased to $6.5 \mathrm{cms}$ and the pregnancy was complicated by polyhydramnios. She needed urgent delivery for abruptio placenta. Conclusion: Though this is the common presentation of placenta chorioangioma, interventions like laser coagulation, alcoholic ablation might have helped to prolong the pregnancy a few more weeks.
\end{abstract}

Keywords: Abruptio Placentae, Hemangioma, Placenta, Polyhydramnios, Pregnancy.

\section{Introduction}

Placental chorioangioma is the most common benign tumor of the placenta. Its incidence is quoted around 1 in 100 placentas and is seen more frequently in multiple pregnancies and in female babies [1]. Chorioangioma is believed to arise by $16^{\text {th }}$ day of fertilization, although there is no documentation of the tumor in the first trimester [2]. In the majority of cases, they are small or microscopic, and of no clinical significance. Rapidly growing large chorioangiomas, more than $4 \mathrm{~cm}$ in size, may be complicated by polyhydramnios, fetal cardiomegaly, followed by hydrops fetalis and intrauterine growth restriction [1].

We hereby report primigravida diagnosed to have a placental chorioangioma of about $4 \mathrm{cms}$ size in routine anomaly scan. At 30 weeks gestation there was an increase in the tumor size to about $6.5 \mathrm{cms}$ and she needed delivery for abruption at 31 weeks. Intervention like amnioreduction, laser endoscopic laser coagulation, and interstitial laser therapy and alcohol injection help to avoid preterm delivery but how much was it was feasible in this case is discussed.

\section{Case Report}

A 23 year old primigravida was referred for routine antenatalbooking to ourhospital. She wasapparently fit with no significant past medical or surgical history. Family history also was unremarkable. The ultrasound done at 22 weeks for anomaly screening revealed a placental mass of $4-4.5 \mathrm{~cm}$ and was diagnosed as placental chorioangioma [Fig.1]. She was offered regular follow up in our hospital as the size of the mass was less than $5 \mathrm{cms}$. Her pregnancy was uneventful till 30 weeks when the placental tumor measured almost $6.5 \mathrm{~cm}$ but the fetal growth, amniotic fluid and biophysical profile were still normal. Plans were made to refer to specialist fetal clinic but at 31 weeks she was admitted with reduced fetal movements and polyhydramnios. Dexamethasone was given for fetal lung maturity and cesarean section had to be done in 48 hours for fetal bradycardia and placental abruption. She delivered a female baby weighing 1530 grams with 
good Apgar score. The macroscopic picture of the placenta soon after delivery is shown in Fig.2. She made an uneventful recovery and the baby did well after a few days' stay in the neonatal unit.

The placental mass was a solid nodular tanbrown tissue $6 \times 6.5 \mathrm{~cm}$ with areas of hemorrhage. On microscopic examination a well circumscribed lesion focally covered by membranes consisting of capillary sized vessels some solid and some with lumina lined by benign endothelial cells (immunoreactive with CD31 and CD34) were seen. Occasional mitotic figures were present. There were focal areas of infarction with calcification. There was no evidence of nuclear atypia or malignancy. Normal placental tissue was not identified [Fig.3]. This case represents the classic features of a large placental chorioangioma with complications like polyhydramnios, preterm labour and abruptio placenta.

\section{Discussion}

Placental chorioangiomas are the most common benign with an incidence of $0.6 \%$ in a large retrospective study by Kuhnel [3]. Marchetti described three histological patterns of chorioangiomas: angiomatous, cellular, and degenerate [4]. The angiomatous is the most common, with numerous small areas of endothelial tissue, capillaries, and blood vessels surrounded by placental stroma.

Small chorioangiomas are asymptomatic but once they reach a size of 4-5 cms they can cause maternal and fetal effects like polyhydramnios, preeclampsia, preterm delivery, nonimmune fetal hydrops, fetal heart failure/cardiomegaly, fetal anemia and thrombocytopenia, fetal growth restriction, fetal hydrops, fetal demise, severe neonatal microangiopathic hemolytic anemia, thrombocytopenia neonatal death, and maternal mirror syndrome [5]. If complications appear late in pregnancy delivery is the choice. Alcohol injection [6], laser coagulation of feeding vessels [7] and micro coil embolization of the feeding

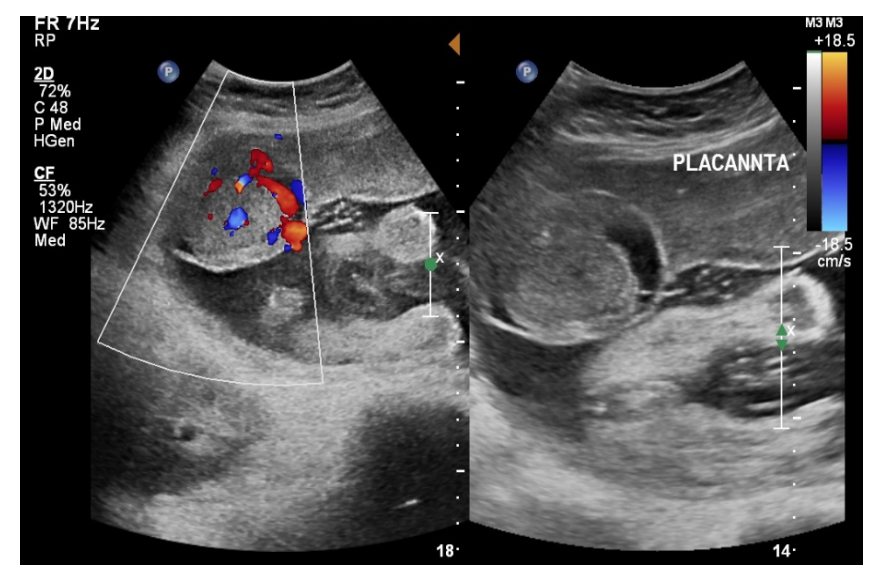

Fig.1: Antenatal ultrasound showing a $4.5 \mathrm{~cm}$ tumor in placenta.

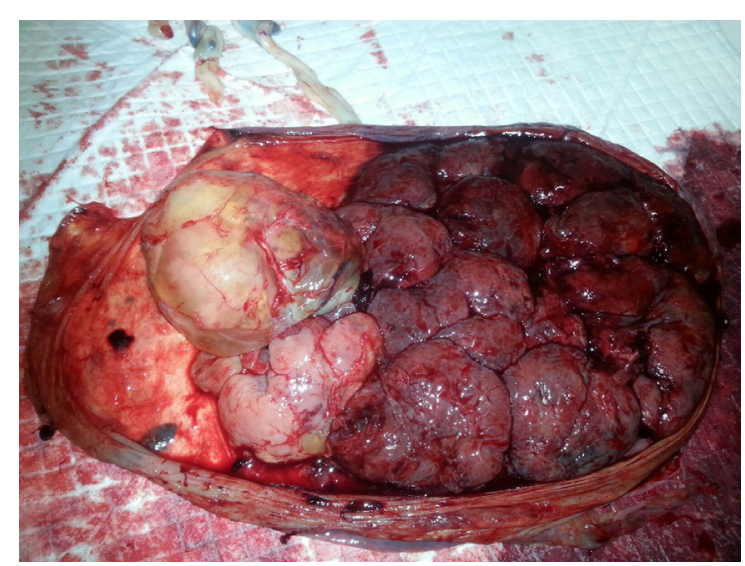

Fig.2: Macroscopic picture of the placenta and tumor immediately after delivery.

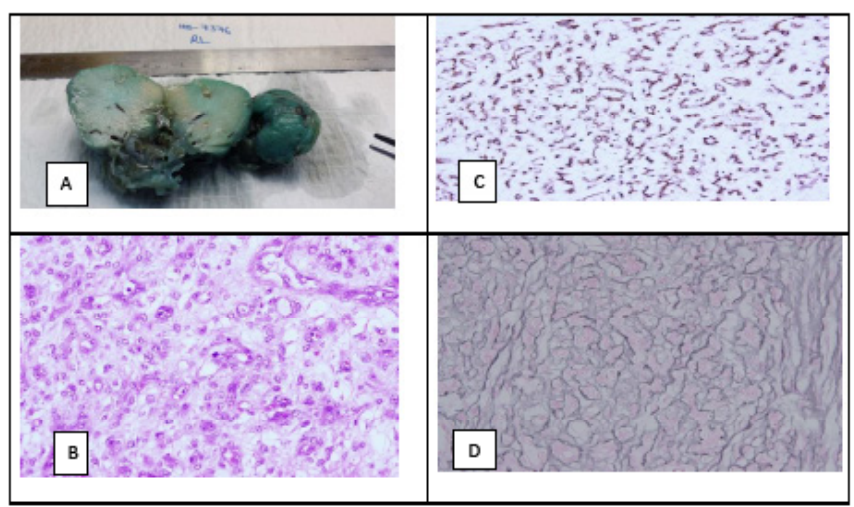

Fig.3(a): Nodular tan lesion with areas of hemorrhage. (b): Closely packed capillaries, solid or with lumina ( $H \& E$ x400). (c): CD 31 staining of the lining endothelial cells (IHC with DAB x100). (d): Reticulin stain outlines the capillary forming lesion (x200). 
vessels [8] are described for women with fetal complications like hydrops. A recent literature review concluded that further studies are needed to refine the appropriate selection criteria that will justify the risk of this invasive in utero therapy for chorioangiomas [9]. Indomethacin therapy for polyhydramnios is another option but not used in this patient as she presented with reduced fetal movements and delivery was imminent. Laser coagulation would have been impossible in this patient due to lack of expertise in the country itself but whether an option like alcohol injection or indomethacin could have been tried is still a question. But the clinical course was very rapid and there was not much time left at 31 weeks gestation.

\section{Conclusion}

Interventions in the form of endoscopic laser coagulation may be useful in selected patients on regular fetal monitoring to avoid preterm delivery in women with big placenta chorioangioma of size $>5 \mathrm{cms}$.

Contributors: All authors have contributed to patient management and manuscript writing. GV will act as guarantor. All authors approved the final version of manuscript. Funding: None; Competing interests: None stated.

\section{References}

1. Guschmann M, Henrich W, Dudenhausen JW. Chorioangiomas-new insights into a well-known problem. II. An immuno-histochemical investigation of 136 cases. J Perinat Med. 2003;31:170-175.

2. Bracero LA, Davidian M, Cassidy S. Chorioangioma: diffuse angiomatous form. 1993-09-18-11 Available at: https://www.hindawi.com/journals/criog/2012/913878. Accessed on September 24, 2016.

3. Kuhnel P. Placental chorioangioma. Acta Obstetricia et Gynecologica Scandinavica.1933;13:143-145.

4. Marchetti AA. A consideration of certain types of benign tumors of the placenta," Surgery, Gynecology \& Obstetrics. 1939;68:733-743.

5. Fan M,Skupski DW. Placental chorioangioma: literature review. J Perinat Med. 2014;42(3):273-279.

6. Nicolini U, Zuliani G, Caravelli E, Fogliani R, Poblete A, Roberts A. Alcohol injection: a new method of treating placental chorioangioma. Lancet. 1999;353:1674-1675.

7. Quarello E, Bernard JP, Leroy B, Ville Y. Prenatal laser treatment of a placental chorioangioma. Ultrasound Obstet Gynecol. 2005;25:299-301.

8. Lau TK, Leung TY, Yu SC, To KF, Leung TN. Prenatal treatment of chorioangioma by microcoil embolization. BJOG. 2003;110:70-73.

9. Hosseinzadeh P, Shamshirsaz AA, Javadian P, Espinoza J, Gandhi M, Ruano R, et al. Prenatal therapy of large placental chorioangiomas: Case Report and Review of the Literature. AJP Rep. 2015;5(2):e196-e202. 